\title{
Total Phenolics, Total Anthocyanins, Antioxidant and Pro-oxidant Activity of Some Red Fruits Teas
}

\author{
Bianca Moldovan, Anamaria Hosu, Luminita David and Claudia Cimpoiu*
}

\author{
Babes-Bolyai University, Faculty of Chemistry and Chemical Engineering, 11 Arany Janos, 400028 Cluj-Napoca, Romania \\ * Corresponding author: E-mail: ccimpoiu@ @hem.ubbcluj.ro \\ Phone: +40264 583833; fax: +40264590818
}

Received: 10-02-2015

\begin{abstract}
Fruits represent one of the main dietary sources of bioactive compounds. Due to their remarkable health benefits, many functional foods of fruit origin, including fruit teas, are present on the market and there is an increased interest regarding the investigation of their nutritional parameters and quality.

The aims of our study were: 1) to determine the total phenolic content (TPC), total anthocyanins content (TAC), antioxidant activity (AA), the scavenging capacity (IC50), the pro-oxidant activity (Pro-ox) and Pro-Antidex of 12 commercially available red fruit teas, 2) to classify the analysed teas and 3) to evaluate the similarities between samples. The TPC was between 12.5 and $29.3 \mathrm{mg}$ gallic acid equivalents (GAE)/g tea, the TAC varied between 2.6 and $5.6 \mathrm{mg}$ cyanidin-3-glucoside (Cy-3-glu)/g tea and AA was in the range of 10.9-19.1 mg ascorbic acid equivalents (AAE)/g tea. The Pro-ox activity varied between 3.9 and $10.0 \mathrm{mg} / \mathrm{mL}$ tea extract and Pro-Antidex was between 3.3 and 7.3.
\end{abstract}

Keywords: Red fruits teas, phenolic compounds, anthocyanins, antioxidant activity, pro-oxidant activity, Pro-Antidex

\section{Introduction}

Phenolic compounds from fruits contribute to their quality, nutritional value, aroma and flavour. They are also known to provide the beneficial health effects of many fruits, such as anti-tumour, anti-ulcer and anti-inflammatory properties, ${ }^{1,2}$ especially due to their high antioxidant activity. Nowadays, sustained efforts are made to find new sources of natural antioxidants.,

Apart from raw fruits and vegetables, plant derived products such as fruits juices, teas and wines are important sources of anthocyanins and other phenolic compounds in the human diet. Fruit tea infusions support the human diet with antioxidants like phenolic compounds, vitamins (C and E), carotenoids. ${ }^{5}$ These infusions are usually obtained from fruits and berries from various genera such as Vaccinum, Rubus, Fragraria and Ribes. The phenolic profile varies among fruits, with certain similarities within families and genera. The major phenolic compound identified in the berries from genus Vaccinium (blueberries and bilberries) was quercetin. In the genus Rubus (raspberry and blackberry) and Fragraria (strawberry, wild strawberry) ellagic acid and ellagitannin are the main phenolic compounds, representing $77-88 \%$ of the total phenolics. The berries belonging to the genus Ribes (blackcurrant) are particularly rich in quercetin. ${ }^{6}$ Quercetin and kaempferol glycosides were also identified in raspberries. ${ }^{7}$ Rose hip fruits are a rich source of vitamin C and phenolics. Quercetin and ellagic acid are the most abundant phenolic compounds of these fruits. ${ }^{8}$ Hibiscus extracts are rich source of phenolic compounds which include phenolic acids, flavonoids and anthocyanins. Caffeic acid, epigallocatechin gallate and protocatechuic acid are the most abundant phenolics found in the dried flowers of Hibiscus sabdariffa. ${ }^{9}$

Phenolic compounds, including anthocyanins, can become pro-oxidants in the presence of transition metal ions (i.e. $\mathrm{Cu}^{2+}$ ) leading to DNA damage by oxidative breakage. The pro-oxidant (Pro-ox) effect is due to the reducing power on iron ions. A predominant reducing power on iron ions over the free radical scavenging activity in a mixture of compounds results in the pro-oxidant effect. ${ }^{10}$ The ratio of pro-oxidant/antioxidant activity expressed as IC50, named Pro-Antidex, enabled to evaluate the net antioxidant capacity of the extracts. This index will include the effective free radical scavenging ability and pro-oxidant effect of the extracts. ${ }^{11}$

There is still a lack of information regarding the fruits teas analysis, in literature only few papers present 
results regarding this subject. ${ }^{12-14}$ Therefore, the objectives of our work were: 1 ) determination of the total phenolic content, the amount of anthocyanins, the antioxidant and pro-oxidant activity and the Pro-Antidex parameter of red fruits teas; 2) classification of teas and 3) checking the similarities between samples using principal component analysis (PCA).

\section{Experimental}

\section{1. Chemicals}

Hydrochloric acid, acetic acid and ethanol were of analytical grade and were purchased from Chimopar (Bucharest, Romania). FolinCiocalteu's reagent $(2 \mathrm{~N})$, gallic acid, 2,2-azinobis(3-ethylbenzothiazoline-6-sulfonic acid) diammonium salt (ABTS), ascorbic acid, potassium ferricyanide, $\mathrm{Na}_{2} \mathrm{CO}_{3}, \mathrm{~K}_{2} \mathrm{~S}_{2} \mathrm{O}_{8}, \mathrm{KCl}, \mathrm{CH}_{3} \mathrm{COONa}$ and trichloroacetic acid were of analytical grade and were purchased from Merck (Darmstadt, Germany).

\section{2. Preparation of Reagents}

The $\mathrm{ABTS}^{\circ+}$ radical-cation was generated by mixing of ABTS solution (7 mM) and $\mathrm{K}_{2} \mathrm{~S}_{2} \mathrm{O}_{8}$ solution $(2.45 \mathrm{mM})$ in volumetric ratio of 1:1. The solution was kept in the dark for $24 \mathrm{~h}$ and was then diluted with water before use so that the absorbance was around 0.800 .

The potassium chloride buffer solution $(0.025 \mathrm{M}, \mathrm{pH}=$ 1) was prepared by dissolving $0.186 \mathrm{~g}$ of potassium chloride in $90 \mathrm{~mL}$ water. The $\mathrm{pH}$ of the resulting solution was adjusted to 1 with concentrated $\mathrm{HCl}$ and the mixture was transferred to $100 \mathrm{~mL}$ volumetric flask and made up with water.

The sodium acetate buffer solution $(0.4 \mathrm{M}, \mathrm{pH}=4.5)$ was prepared from $1.959 \mathrm{~g}$ of $\mathrm{CH}_{3} \mathrm{COONa} \cdot 3 \mathrm{H}_{2} \mathrm{O}, 1.48$ $\mathrm{mL}$ of glacial acetic acid and water (filling up to $100 \mathrm{~mL}$ ).
The solution of Folin-Ciocalteu reagent $(0.2 \mathrm{~N})$ was prepared by diluting the Folin-Ciocalteu's reagent $(2 \mathrm{~N})$. The aqueous solutions of $\mathrm{Na}_{2} \mathrm{CO}_{3}(0.7 \mathrm{M})$, potassium ferricyanide $(1 \%)$, trichloroacetic acid $(10 \%)$ and $\mathrm{FeCl}_{3}$ $(0.1 \%)$ were also prepared.

\section{3. Preparation of Gallic Acid and Ascorbic Acid Standard Solutions}

The gallic acid stock solution $(1 \mathrm{mg} / \mathrm{mL})$ was prepared by dissolving $100 \mathrm{mg}$ of anhydrous gallic acid in 2 $\mathrm{mL}$ of ethanol and filling up a $100 \mathrm{~mL}$ volumetric flask with water. Working solutions $(10,20,30,50,100 \mu \mathrm{g} / \mathrm{mL})$ were prepared by dilution of the stock solution with water.

The ascorbic acid stock solution $(1.5 \mathrm{mg} / \mathrm{mL})$ was prepared by dissolving anhydrous ascorbic acid in water. Working solutions $(15,30,45,75,150 \mu \mathrm{g} / \mathrm{mL})$ were prepared by dilution of the stock solution with water.

\section{4. Tea Samples and Preparation of the Extracts}

Twelve commercially available fruit teas of different flavours from three different producers were purchased from a local supermarket. These samples contained various amounts of fruits and calyces of Hibiscus sabdariffa L. were selected as they are frequently consumed and widely appreciated (Table 1).

Three independent extracts of each selected tea were prepared by infusing $1 \mathrm{~g}$ of each tea in $100 \mathrm{~mL}$ of water heated at $95{ }^{\circ} \mathrm{C}$, for $5-10$ minutes, according to the instructions provided on the packaging. The extracts were filtered, cooled at room temperature and directly analyzed without any other treatments to determine the total phenolic content, total anthocyanins content, antioxidant activity and pro-oxidant activity. All the samples were suitably di-

Table 1. The fruit composition of investigated teas.

\begin{tabular}{|c|c|c|c|c|}
\hline No. & Type of fruit tea ${ }^{a}$ & Fruit ingredients $^{b}$ & $\begin{array}{c}\text { Time of } \\
\text { infusion (min) }\end{array}$ & Producer \\
\hline 1 & Raspberry & Raspberry, hibiscus, blackcurrant, blueberry & 5 & $\mathrm{~A}$ \\
\hline 2 & Raspberry & Raspberry, blackcurrant, hibiscus & 8 & $\mathrm{~B}$ \\
\hline 3 & Blueberry & Blueberry, hibiscus, blackcurrant & 5 & A \\
\hline 4 & Blueberry & Blueberry, blackcurrant, strawberry, hibiscus & 8 & $\mathrm{~B}$ \\
\hline 5 & Rosehip & Rosehip, hibiscus, blackcurrant & 5 & A \\
\hline 6 & Rosehip & Rosehip, blackcurrant, hibiscus & 8 & $\mathrm{~B}$ \\
\hline 7 & Strawberry & Strawberry, blackcurrant, hibiscus & 8 & $\mathrm{~B}$ \\
\hline 8 & $\begin{array}{l}\text { Strawberry and } \\
\text { wild strawberry }\end{array}$ & Hibiscus, rose hip, strawberry, raspberry, cherry, wild strawberry & 10 & $\mathrm{C}$ \\
\hline 9 & Wild berry & Blueberry, blackcurrant, blackberry, hibiscus & 5 & A \\
\hline 10 & Wild berry & Blackberry, raspberry, wild strawberry, blueberry, rose hip, hibiscus & 5 & A \\
\hline 11 & Wild berry & Blackberry, blackcurrant, raspberry, strawberry, hibiscus & 8 & $\mathrm{~B}$ \\
\hline 12 & Wild berry & Hibiscus, rose hip, raspberry, blueberry, blackberry, strawberry, cherry & 10 & $\mathrm{C}$ \\
\hline
\end{tabular}

\footnotetext{
${ }^{\text {a }}$ All teas were as bags, except tea no. 10 that was a mixture of dry fruit pieces

${ }^{b}$ The fruits are listed in decreasing order of their amount, as labelled by the producer
} 
luted before spectrophotometric determination so that the values of absorbance were in the range of $0.200-0.800$.

Tea extracts with various concentrations $(0.36$ $\mathrm{mg} / \mathrm{mL}-5 \mathrm{mg} / \mathrm{mL}$ ) were prepared by infusing the proper quantity of each tea in warm water. These extracts were used for the IC50 determinations.

\section{5. Spectrophotometric Measurements}

All spectrophotometric measurements were made at room temperature $\left(\sim 22{ }^{\circ} \mathrm{C}\right)$ using a double-beam spectrophotometer $\mathrm{T} 80+$ (PG Instruments, Lutterworth, United Kingdom).All the determinations were done in triplicate.

\section{5. 1. Total Phenolic Content (TPC)}

Total phenolic content was determined using FolinCiocalteu reagent according to Singleton method. ${ }^{15}$ Aliquots $(0.3 \mathrm{~mL})$ of diluted tea extracts were mixed with 1.5 $\mathrm{mL}$ Folin-Ciocalteu solution and $1.2 \mathrm{~mL}$ of $\mathrm{Na}_{2} \mathrm{CO}_{3}$ solution was added after $5 \mathrm{~min}$. Then the mixtures were incubated at room temperature in the dark for $2 \mathrm{~h}$, and their absorbance was measured at $760 \mathrm{~nm}$ against a blank sample as the reference. Total phenolic contents were calculated using a calibration curve for gallic acid $(0-100 \mu \mathrm{g} / \mathrm{mL})$ and the results were expressed as $\mathrm{mg}$ of gallic acid equivalents (GAE)/g tea.

\section{5. 2. Total Anthocyanins Content (TAC)}

The $\mathrm{pH}$-differential method ${ }^{16}$ was used to determine the total anthocyanins content, using two buffer systems. Aliquots of fruits tea extracts $(1 \mathrm{~mL})$ were diluted with $3 \mathrm{~mL}$ of corresponding buffer $(\mathrm{KCl} / \mathrm{HCl}$ buffer, $0.025 \mathrm{M}$, $\mathrm{pH}=1$ and $\mathrm{CH}_{3} \mathrm{COONa} / \mathrm{CH}_{3} \mathrm{COOH}$ buffer, $0.4 \mathrm{M}, \mathrm{pH}=$ 4.5). After 15 minutes, the absorbance of each solution was measured at $512\left(\lambda_{\text {VIS max }}\right)$ and at $700 \mathrm{~nm}$ (for haze correction).TAC was calculated as equivalents of cyanidin-3-glucoside (Cy-3-glu)/g tea, using the following equation:

$$
\mathrm{TAC}=(\mathrm{A} \cdot \mathrm{MW} \cdot \mathrm{DF} \cdot 1000) /(\varepsilon \cdot 1)
$$

where: $\mathrm{TAC}=$ total anthocyanins content $(\mathrm{mg} / \mathrm{L}) ; \mathrm{MW}=$ molecular weight $(449.2 \mathrm{~g} / \mathrm{mol}) ; \mathrm{DF}=$ dilution factor (4); $1=$ path length $(1 \mathrm{~cm}) ; \varepsilon=$ molar extinction coefficient $(26900 \mathrm{~L} / \mathrm{mol} \cdot \mathrm{cm})^{14} ; 1000=$ conversion factor from gram to milligram and $\mathrm{A}=$ absorbance, calculated by following equation:

$$
\begin{aligned}
\mathrm{A}= & \left(\mathrm{A}_{\mathrm{pH} 1.0}-\mathrm{A}_{\mathrm{pH} 4.5}\right)_{512 \mathrm{~nm}}- \\
& -\left(\mathrm{A}_{\mathrm{pH} 1.0}-\mathrm{A}_{\mathrm{pH} 4.5}\right)_{700 \mathrm{~nm}}
\end{aligned}
$$

\section{5. 3. Antioxidant Activity (AA)}

The antioxidant activity was determined by the ABTS assay according to the method of Re et al. ${ }^{17}$ with some modifications. ${ }^{18}$ The tea extract $(0.5 \mathrm{~mL})$ was mixed with $3 \mathrm{~mL} \mathrm{ABTS}^{\cdot+}$ solutionand after 15 minutes the absorbance was measured at $734 \mathrm{~nm}$. The antioxidant activity calculated using the calibration curve for ascorbic acid $(15-150 \mu \mathrm{g} / \mathrm{mL})$ was expressed as $\mathrm{mg}$ ascorbic acid equivalents (AAE)/g tea.

Scavenging activity of teas was expressed as IC50, which represents the concentration of the extract (mg of tea/mL of extract) required to inhibit $50 \%$ of the free radical scavenging activity. The absorbance of extracts treated with $\mathrm{ABTS}^{-+}$as above was measured and the percentage of free radical inhibition were calculated. The IC50 values were calculated by linear regression of plots representing the concentrations of tested tea extracts, against the percentage of free radical scavenging activities. $^{19}$

\section{5. 4. Pro-oxidant Activity (Pro-ox)}

Pro-oxidant activities were determined by the following method: ${ }^{19}$ equal volumes $(2 \mathrm{~mL})$ of the tea solution diluted with water for 2, 4, 6, 8 and 10 times, and potassium ferricyanide solution were mixed and were incubated at $50{ }^{\circ} \mathrm{C}$ for $20 \mathrm{~min}$. After that, $2 \mathrm{~mL}$ of trichloroacetic acid solution was added and the mixture was centrifuged (Centurion Scientific centrifuge C2006, Bosham, UK) for $10 \mathrm{~min}$ at $875 \mathrm{~g}$. The supernatant $(2 \mathrm{~mL})$ was mixed with $2 \mathrm{~mL}$ of water and $0.5 \mathrm{~mL}$ of $\mathrm{FeCl}_{3}$ solution. The absorbance of obtained solution was measured at $700 \mathrm{~nm}$ using water as a blank. The pro-oxidant activities were calculated from linear regression obtained by plotting the absorbance of the tea extracts against their concentrations and were expressed as concentration $(\mathrm{mg} / \mathrm{mL})$ for absorbance set to the arbitrary value 1.000 .

The net antioxidant potential expressed as the ProAntidex index was calculated for each tea as the ratio of their pro-oxidant activity $(\mathrm{mg} / \mathrm{mL})$ to the IC50 value $(\mathrm{mg} / \mathrm{mL})$.

$$
\text { Pro-Antidex }=\text { Pro-ox/IC50 }
$$

\section{6. Statistical Analysis}

The data reported are presented as mean \pm standard deviations from at least three independent experiments. The results were processed using one-way variance analysis (ANOVA) using StatistiXL. Differences were considered statistically significant in the case of $p<0.05$ for probability $\mathrm{P} \geq 95 \%$. In order to classify the teas based on the obtained experimental data the principal component analysis (PCA) was performed.

\section{Results and Discussions}

All the experimental results are presented in Table 2. 
Table 2. The total phenolic content (TPC - mg GAE/g fruit tea), total anthocyanins content (TAC - mg Cy-3-gly/g fruit tea), antioxidant activity (AA- mg AAE/g fruit tea), IC50 $(\mathrm{mg} / \mathrm{mL})$, pro-oxidant activity $(\mathrm{mg} / \mathrm{mL})$ and Pro-Antidex of the analyzed teas $(\mathrm{n}=9)$.

\begin{tabular}{ccccccc}
\hline No.(producer) & TPC & TAC & AA & IC50 & Pro-ox & Pro-Antidex \\
\hline 1 (A) & $15.84 \pm 0.15$ & $4.49 \pm 0.20$ & $12.95 \pm 1.62$ & $1.21 \pm 0.01$ & $6.12 \pm 0.04$ & $5.06 \pm 0.01$ \\
2 (B) & $12.53 \pm 0.15$ & $3.65 \pm 0.09$ & $15.19 \pm 2.50$ & $2.18 \pm 0.07$ & $9.79 \pm 0.08$ & $4.48 \pm 0.01$ \\
3 (A) & $23.23 \pm 0.42$ & $5.57 \pm 0.37$ & $18.27 \pm 0.17$ & $0.99 \pm 0.01$ & $5.34 \pm 0.04$ & $5.40 \pm 0.00$ \\
4 (B) & $13.89 \pm 0.20$ & $4.39 \pm 0.21$ & $12.96 \pm 1.62$ & $1.31 \pm 0.02$ & $9.50 \pm 0.06$ & $7.35 \pm 0.05$ \\
5 (A) & $18.61 \pm 0.22$ & $5.26 \pm 0.01$ & $15.41 \pm 0.33$ & $0.93 \pm 0.00$ & $6.08 \pm 0.03$ & $6.55 \pm 0.02$ \\
6 (B) & $28.18 \pm 0.40$ & $2.84 \pm 0.12$ & $10.96 \pm 0.30$ & $1.40 \pm 0.02$ & $8.02 \pm 0.05$ & $5.71 \pm 0.02$ \\
7 (B) & $15.54 \pm 0.07$ & $4.58 \pm 0.46$ & $13.13 \pm 1.96$ & $1.79 \pm 0.02$ & $8.69 \pm 0.06$ & $4.85 \pm 0.03$ \\
8 (C) & $29.33 \pm 0.20$ & $4.16 \pm 0.09$ & $19.02 \pm 0.22$ & $0.86 \pm 0.04$ & $3.91 \pm 0.03$ & $4.54 \pm 0.02$ \\
9 (A) & $18.22 \pm 0.11$ & $5.14 \pm 0.08$ & $13.42 \pm 0.30$ & $1.13 \pm 0.01$ & $5.89 \pm 0.05$ & $5.23 \pm 0.02$ \\
1 (A) & $16.36 \pm 0.46$ & $2.62 \pm 0.34$ & $11.24 \pm 0.04$ & $1.30 \pm 0.03$ & $5.66 \pm 0.04$ & $4.35 \pm 0.04$ \\
11 (B) & $13.28 \pm 0.17$ & $3.61 \pm 0.21$ & $10.87 \pm 2.51$ & $3.06 \pm 0.01$ & $10.00 \pm 0.05$ & $3.28 \pm 0.01$ \\
12 (C) & $14.13 \pm 0.13$ & $4.04 \pm 0.33$ & $19.06 \pm 1.96$ & $0.88 \pm 0.03$ & $4.03 \pm 0.19$ & $4.58 \pm 0.05$ \\
\hline
\end{tabular}

\section{1. Total Phenolic Content (TPC)}

The TPC of the investigated tea extracts was evaluated based on their reduction properties and was determined by Folin-Ciocalteu method (Table 2). The highest TPC of teas from producer A was found for the blueberry tea $(23.23 \pm 0.42 \mathrm{mg} \mathrm{GAE} / \mathrm{g}$ fruit tea), the lowest value being exhibited by the raspberry tea $(15.84 \pm 0.15 \mathrm{mg}$ $\mathrm{GAE} / \mathrm{g}$ fruit tea). There is a 1.4-fold difference between the lowest and the highest TPC values of the investigated teas of this producer. Regarding the teas made by producer B, the TPC was found to be higher in rose hip infusion $(28.18 \pm 0.40 \mathrm{mg}$ GAE$/ \mathrm{g}$ fruit tea) while the lowest value was obtained for the raspberry tea $(12.53 \pm 0.15 \mathrm{mg}$ GAE/g fruit tea). There is a 2.2 -fold difference between the highest and the lowest TPC values of the teas. The highest TPC value of all investigated teas was found for the strawberry tea from the teas made by producer $\mathrm{C}$, probably due to its high content of hibiscus and rose hip fruit (as labelled by producer).

The TPC of the investigated teas varied widely especially from one tea producer to the other. Differences were also observed among teas from the same producer due to different fruit ingredients in each tea. The determined TPC values from 12.53 to $29.33 \mathrm{mg}$ GAE/g fruit tea (126.07 to $295.02 \mathrm{mg}$ GAE/L infusion) are in agreement with 323.4-1549.1 mg GAE/L infusion reported for two times more concentrated infusions $(2 \mathrm{~g}$ tea/ $100 \mathrm{~mL}$ water $)$ prepared from similar fruit teas. ${ }^{5}$ As expected, these values are much lower as the TPC of the fruit juices - blueberry 179.5; strawberry 1302; blackcurrant $1919 \mathrm{mg}$ $\mathrm{GAE} / \mathrm{L},{ }^{20}$ due to the fact that fruit tea manufacturing involves processing procedures (such as drying, grinding) that may determine the degradation of the phenolic compounds.

\section{2. Total Anthocyanins Content (TAC)}

The TAC of the fruit tea infusions was investigated using the $\mathrm{pH}$ differential method. The anthocyanins levels were similar in all fruit infusions from producer A (in the range of 4.49-5.57 mg Cy-3-glu/g fruit tea), except for wild berry tea no. 10, which had the lowest TAC (2.62 \pm $0.34 \mathrm{mg} \mathrm{Cy}-3$-glu/g fruit tea). Furthermore, a statistically significant correlation was found between the TAC and the TPC $(r=0.9068$ and $p=0.093)$. For producer $B$, except the rose hip tea no. $6(2.84 \pm 0.12 \mathrm{mg}$ Cy-3-glu/g fruit tea), similar TAC values were found for the investigated fruit infusions (in the range of 3.61-4.58 mg Cy-3-glu/g fruit tea). As in the previous case, the TAC values followed the same trend as the TPC values, being statistically correlated $(r=0.8775$ and $p=0.12)$. The determined TAC values for the fruit tea infusions of producer $\mathrm{C}$ are almost the same ( $4 \mathrm{mg} \mathrm{Cy}-3$-glu/g fruit tea).

The lowest TAC was found for the rose-hip fruit tea no. 6 (producer B), being 1.85 fold lower as the TAC determined for the rose-hip fruit tea no. 5 (producer A). By comparing these values, it is important to take into account the fruit composition of analysed teas (Table 1). This result may be due to the fact that tea no. 6 contains a lower quantity of blackcurrant (berries that have higher TAC than rose-hip fruits) compared to the tea no.5. This difference may also explain the lower than expected TPC value determined for tea no. 5 .

Since there is no published report about the TAC of infusions prepared from bagged fruit teas, we can only compare our data with those reported for the TAC of juices prepared from the same fruits as our tea samples. It was reported that blueberry and strawberry juices contain 424.1 to $518.2 \mathrm{mg} \mathrm{Cy}-3-\mathrm{glu} / \mathrm{L},{ }^{21}$ and $55.7 \mathrm{mg} \mathrm{Cy}-3-$ $\mathrm{glu} / \mathrm{L},{ }^{22}$ respectively. Also, blackberry and cherry fruits contain $198.25 \mathrm{mg}$ Cy-3-glu $\cdot 100 \mathrm{~g}^{-1}$ fresh matter, and $44.19 \mathrm{mg}$ Cy-3-glu $\cdot 100 \mathrm{~g}^{-1}$ fresh matter. ${ }^{23}$ As expected, the TAC of the investigated teas (in the range 26.4-56.06 $\mathrm{mg}$ Cy-3-glu/L tea extract) was much lower.

\section{3. Antioxidant Activity (AA)}

Antioxidant activities of all 12 fruit tea infusions were determined using the ABTS assay, which is based on 
the ability of antioxidants to perform as free radical scavengers. ${ }^{24}$ Significant differences were observed among various tea infusions. The highest ABTS radical cation scavenging activity was exhibited by the blueberry tea of producer $\mathrm{A}(18.27 \pm 0.17 \mathrm{mg} \mathrm{AAE} / \mathrm{g}$ fruit tea) and by the raspberry tea $(15.19 \pm 2.50 \mathrm{mg} \mathrm{AAE} / \mathrm{g}$ fruit tea) of producer B, respectively. The lowest AA values were determined for the wild berry tea no. 10 of producer A (11.24 \pm $0.04 \mathrm{mg} \mathrm{AAE} / \mathrm{g}$ fruit tea) and for the wild berry tea no. 11 $(10.87 \pm 2.51 \mathrm{mg} \mathrm{AAE} / \mathrm{g}$ fruit tea) of producer B. There is a 1.4-fold difference between the lowest and the highest AA values of the investigated teas of producer $A$, the same as for the TPC values. A statistically significant relationship between TPC and AA was observed $(r=0.9529$ and $p=0.046$ ), indicating that the concentration of phenolic compound may be a good indicator of the AA of the investigated fruit tea infusions. Surprisingly, no correlation between TPC and AA was observed in teas of producer B. The determined AA for the fruit tea infusions from producer $\mathrm{C}$ was almost the same ( $19 \mathrm{mg} \mathrm{AAE} / \mathrm{g}$ fruit tea), and was the highest of the all investigated teas.

As expected, the studied tea infusions exhibit a significantly lower AA (in the range of $10.9-15.4 \mathrm{mg}$ AAE/100 mL infusion) compared to conventional teas of Camelia Sinensis (L.) (106 mg AAE/100 mL - black tea, $131 \mathrm{mg} \mathrm{AAE} / 100 \mathrm{~mL}$ - green tea, $83 \mathrm{mg} \mathrm{AAE} / 100 \mathrm{~mL}$ oolong tea ${ }^{25}$ ).

\section{4. Pro-oxidant Activity}

The method applied for the evaluation of pro-oxidant activity of studied tea infusions is based on their reducing power of iron ion in a Fenton reaction. ${ }^{11}$ The prooxidant activities calculated at an absorbance set at an arbitrary value of 1.000 are reported in Table 2 . Significant differences were observed among the pro-oxidant activities of the investigated fruit teas. The highest pro-oxidant activity was exhibited by the raspberry tea of producer $\mathrm{A}$
$(6.12 \pm 0.04 \mathrm{mg} / \mathrm{mL})$ and by the wild berry tea of producer $B(10.00 \pm 0.05 \mathrm{mg} / \mathrm{mL})$. The lowest pro-oxidant activities were found for both tea from producer C, $3.909 \pm$ $0.028 \mathrm{mg} / \mathrm{mL}$ for the strawberry and wild strawberry tea, and $4.03 \pm 0.12 \mathrm{mg} / \mathrm{mL}$ for wild berry tea, respectively. The results also indicate that the pro-oxidant activity of each type of tea from the producer B was higher than those of the corresponding tea from the producer A, differences being between 1.3-fold (rose-hip teas) and 1.8-fold (blueberry teas). Moreover, it could be observed that the pro-oxidant activity of teas from the producer $\mathrm{B}$ are higher than those from the producer $\mathrm{C}$ by more than 2.2 -fold (e.g. 10.00 vs 4.03 for wildberry tea).

Considering the scavenging activity of teas expressed as IC50, the Pro-Antidex values were calculated. This index offer a useful information on the real antioxidant capacity of fruit tea extracts. A lower value of Pro-Antidex indicates that the sample possess a lower pro-oxidant activity. ${ }^{11}$ Therefore, it would be expected that the tea will be more efficient in neutralizing free radicals.

The results indicate that among the teas of producer A the wild berry tea infusion (tea no. 10) has the lowest Pro-Antidex value $(4.35 \pm 0.04)$. From the teas of producer B, tea no. 11 (wild berry tea) possess the lowest ProAntidex value $(3.28 \pm 0.01)$. Comparing the Pro-Antidex values for teas of producer $\mathrm{C}$, it could be observed that the strawberry and wild strawberry tea has a lowest index value $(4.54 \pm 0.02)$. Considering all twelve samples, the results show that the blueberry tea from the producer B has the highest Pro-Antidex value $(7.35 \pm 0.05)$.

The correlation between pro-oxidant activity and antioxidant activity (Figure 1) was acceptable (AA versus Pro-ox $-r=0.6374$ and IC50 versus Pro-ox $-r=0.8023$ ), but it would be better to take into account both free radical scavenging activity and pro-oxidant activity for the evaluation of the real antioxidant activity of the fruit teas.

The classification was accomplished by principal component analysis, which combined the experimental
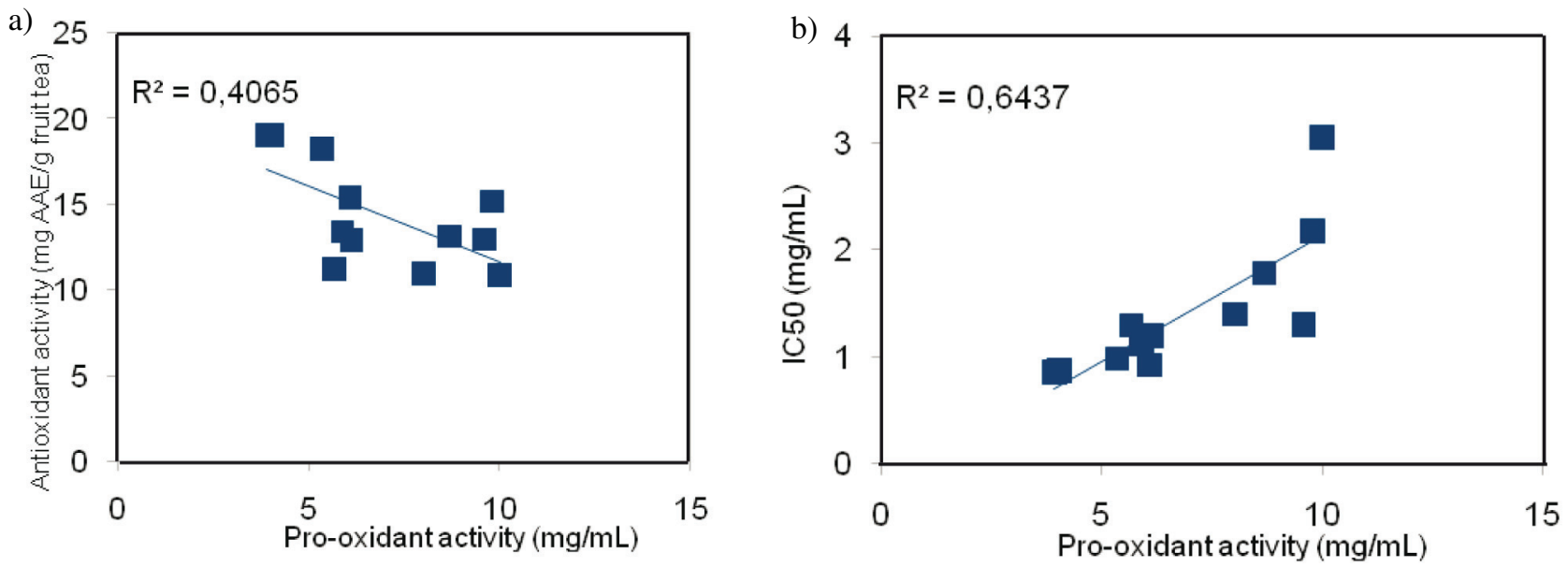

Figure 1.The correlation between Pro-oxidant activity and antioxidant activity (a), respectively Pro-oxidant activity and IC50 (b). 


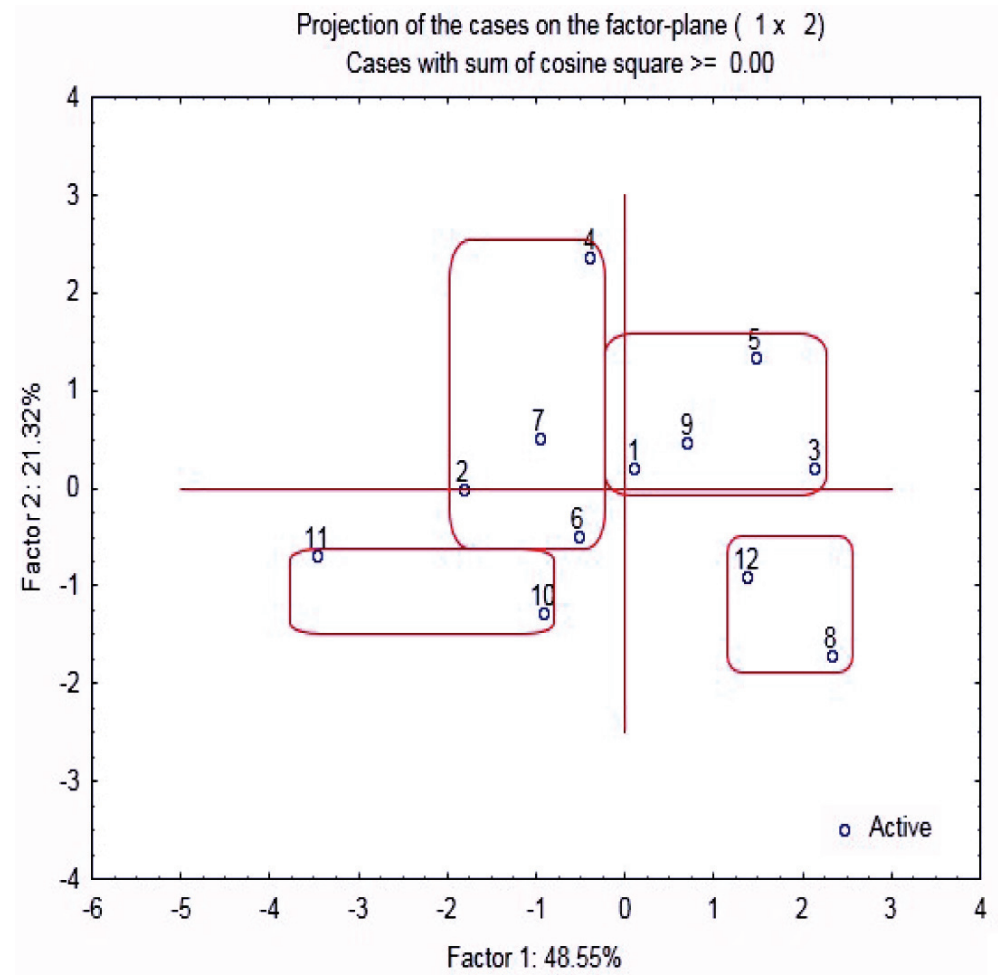

Figure 2. PC1-PC2 scores plot obtained using the TPC, TAC, AA, IC50, Pro-ox and Pro-Antidex values.

results into a data matrix highlighting the similarities and differences of teas. On the PC1-PC2 scores plot (Figure 2) four clusters related to the tea producers are observed.

Thus, the cluster containing the teas no.1, 3, 5 and 9 represents the producer $\mathrm{A}$, while the cluster including the teas no.2, 4, 6 and 7 corresponds to producer B. The third cluster encloses the teas no. 8 and 12 made by producer $\mathrm{C}$. Tea no. 10 (producer A) and tea no. 11 (producer B) are excepted from this classification being grouped in a separate cluster. This behaviour may be due to the fact that these teas are mixtures of pieces of fruits, while the others are bagged teas.

\section{Conclusions}

This paper reports key information on the total phenolic and anthocyanin content, the antioxidant and prooxidant properties of different commercially available fruit teas. The investigated teas exhibited different TPC, TAC, AA, Pro-ox and Pro-Antidex values, which varied widely with their composition. The statistical analysis confirms that the characteristics of teas differ significantly depending on the producer.

The TAC, TPC and AA of studied teas decreases in the order: blueberry $>$ wild berry $>$ raspberry $>$ strawberry. Since the determination of the antioxidant and pro- oxidant activity of fruit teas do not provide enough information regarding their net free radical scavenging ability, the Pro-Antidex values should be taken into account.

Even if the level of biologically active compounds is lower than in black, green or white teas, fruit teas still remain an important source of antioxidants to human diet.

\section{Acknowledgments}

This research is supported by Executive Unit for Financing Education Higher, Research Development and Innovation, project number PN-II-PT-PCCA-2011-3-10914.

\section{References}

1. Konczak-Islam, M. Yoshimoto, D. X. Hou, N. Terahara, O. Yamakawa, J. Agric. Food Chem. 2003, 51, 5916-5922. http://dx.doi.org/10.1021/jf030066o

2. F. C. Stintzing, R. Carle, Trends Food Sci. Tech. 2004, 15, 19-38. http://dx.doi.org/10.1016/j.tifs.2003.07.004

3. I. Ignat, I. Volf, V. I. Popa, Food Chem. 2011, 126, 18211835. http://dx.doi.org/10.1016/j.foodchem.2010.12.026

4. J. Kristl, A. U. Krajnc, B. Kramberger, S. G. Mlakar, Acta Chim. Slov. 2013, 60, 19-25.

5. A. Belščak, N. Bukovac, J. Piljac-Žegarac, J. Food Biochem.2011, 35, 195-212. http://dx.doi.org/10.1111/j.1745-4514.2010.00375.x 
6. B. Tian, Y. Hu, Food Chem. 2005, 91, 413-418. http://dx.doi.org/10.1016/j.foodchem.2004.06.018

7. L. T. Ling, U. D. Palanisamy, H. M. Cheng, Molecules 2010 , 15, 7884-7892. http://dx.doi.org/10.3390/molecules15117884

8. M. Polovka, V. Brezová, A. Staško, Biophys. Chem.2003, 106, 39-56. http://dx.doi.org/10.1016/S0301-4622(03)00159-5

9. K. Šavikin, G. Zdunić, T. Janković, D. Gođevac, T. Stanojković, D. Pljevljakušić, Food Res. Int. 2014, 62, 677-683. http://dx.doi.org/10.1016/j.foodres.2014.04.017

10. L. David, A. Hosu, B. Moldovan, C. Cimpoiu, J. Liq. Chromatogr. Rel. Technol. 2014, 37, 1644-1653. http://dx.doi.org/10.1080/10826076.2013.803206

11. V. L. Singleton, R. Orthofer, R. M. Lamuela-Raventos, in: L. Packer (Ed.): Methods in Enzymology, Academic Press, San Diego, USA, 1999, Vol. 299.

12. M. M. Giusti, R. E. Wrolstad, Curr. Protocols Food Anal. Chem.2001, F1.2:1-13.

13. R. Re, N. Pellegrini, A. Proteggente, A. Pannala, M. Yang, C. Rice-Evans, Free Radical Bio. Med., 1999, 26, 1231-1237. http://dx.doi.org/10.1016/S0891-5849(98)00315-3

14. B. Moldovan, O. Ghic, L. David, C. Chisbora, Rev. Chim. (Bucharest), 2012, 63, 463-464.

15. L. T. Ling, S. A. Yap, A. K. Radhakrishnan, T. Subramaniam, H. M. Cheng, U. D. Palanisamy, Food Chem. 2009, 113, 1154-1159. http://dx.doi.org/10.1016/j.foodchem.2008.09.004

16. S. Hakkinen, M. Heinonen, S. Karenlampi, H. Mykkanen, J. Ruuskanen, R. Torronen, Food Res. Int., 99, 32, 345-353.
17. W. Mullen, J. McGinn, M. E. J. Lean, M. R. MacLean, P. Gardner, G. G. Duthie, T. Yokota, A. Crozier, J. Agric. Food Chem., 2002, 50, 5191-5196. http://dx.doi.org/10.1021/jf020140n

18. V. T. Tumbas, J. M. Canadanovic-Brunet, D. D. CetojevicSimin, G. S. Cetkovic, S. M. Dilas, L. Gille, J. Sci. Food Agric., 2012, 92, 1273-1281. http://dx.doi.org/10.1002/jsfa.4695

19. H. H. Lin, H. P. Huang, C. C. Huang, J. H. Chen, C. J. Wang, Mol. Carcinogen., 2005, 43, 86-89. http://dx.doi.org/10.1002/mc.20103

20. J. Piljac-Žegarac, L. Valek, S. Martinez, A. Beľšča, Food Chem. 2009, 113, 394-400. http://dx.doi.org/10.1016/j.foodchem.2008.07.048

21. R. Margerita, E. Giussania, R. Morelli, R. L. Scalzoc, R. C. Nani, D. Torreggiani, Food Res. Int. 2003, 36, 999-1005. http://dx.doi.org/10.1016/j.foodres.2003.07.002

22. 22. D. Torreggiani, E. Forni, I. Guercilena, A. Maestrelli, G. Bertolo, G. P. Archer, C. J. Kennedy, S. Bone, G. Blond, E. Contreras-Lopez, D. Champion, Food Res. Int. 1999, 32, 441-446. http://dx.doi.org/10.1016/S0963-9969(99)00106-4

23. S. Oancea, C. Grosu, O. Ketney, M. Stoia, Acta Chim. Slov. 2013, 60,383-389.

24. Y. Y. Lim, T. T. Lim, J. J. Tee, Food Chem. 2007, 103, 10031008. http://dx.doi.org/10.1016/j.foodchem.2006.08.038

25. P. Deetae, P. Parichanon, P. Trakunleewatthana, C. Chanseetis, S. Lertsiri, Food Chem. 2012, 133, 953-959. http://dx.doi.org/10.1016/j.foodchem.2012.02.012

\section{Povzetek}

Sadje spada med glavne prehranske vire bioaktivnih spojin. Zaradi pozitivnih učinkov na zdravje, je na trgu prisotnih veliko funkcionalnih živil narejenih iz sadja in tudi sadnih čajev, veča pa se tudi zanimanje za raziskave njihove hranilne vrednosti in kakovosti. Cilji naše raziskave so bili: 1) določitev vsebnosti skupnih fenolnih spojin (TPC), vsebnosti skupnih antocianinov (TAC), antioksidativne aktivnosti (AA), koncentracije učinkovitosti (IC50), prooksidativneaktivnosti (Pro-ox) in »Pro-Antidex « 12 komercialno dostopnih sadnih čajev; 2) klasifikacija analiziranih čajev; 3) ocena podobnosti vzorcev. TPC je bila med 12,5 in 29,3 mg ekvivalentov galne kisline (GAE) / g čaja, TAC med 2,6 in 5,6 mg cianidin-3-glukozida (Cy-3-glu) / g čaja, AA pa v območju od 10,9 do 19,1 mgaskorbinske kisline (AAE) / g čaja. Proox je bila v območju od 3,9 do $10,0 \mathrm{mg} / \mathrm{mL}$ ekstrakta čaja, Pro-Antidex pa od 3,3 do 7,3. 